\title{
ПЕРВЫЕ ШАГИ ПРАВИТЕЛЬСТВА МОСКВЫ ПО ПРЕОДОЛЕНИЮ КРИЗИСА ПЕРЕХОДНОГО ПЕРИОДА В НАЧАЛЕ 1990-Х ГГ.
}

\section{THE FIRST STEPS OF THE MOSCOW GOVERNMENT TO OVERCOME THE CRISIS OF THE TRANSITION PERIOD IN THE EARLY 1990S}

A. Shchukin

Summary: The post-Soviet period in the history of our country was marked by a deep socio-economic crisis. In the early 1990s, the capital's authorities faced many challenges: discord in the mechanism of city management, disintegration of economic relations with regions, depression in the economy. The article is devoted to the main areas of activity of the Moscow Government and the mayor to overcome the crisis. The main events considered in the article: the formation of the Moscow government, the adoption of the socio-economic program for the development of the city in 1991, the Moscow privatization program, a set of measures in the field of housing construction.

Keywords: recent history of Russia, 1990s, Moscow, The government of Moscow, market reforms, privatization, Yuri Luzhkov.

\author{
Щукин Алексей Александрович \\ Аспирант, Московский городской \\ педагогический университет \\ AAShchukin95@yandex.ru
}

Аннотация: Постсоветский период в истории нашей страны ознаменовался глубоким социально-экономическим кризисом. В начале 1990-х годов власти столицы столкнулись с множеством вызовов: разлад в механизме управления городом, распад хозяйственных связей с регионами, депрессия в экономике. Статья посвящена основным направлениям деятельности Правительства Москвы и мэра по преодолению кризиса. Основные события, рассматриваемые в статье: формирование московского правительства, принятие социально-экономической программы развития города в 1991 г., московская программа приватизации, комплекс мер в области жилищного строительства.

Ключевые слова: новейшая история России, 1990-е гг., Москва, Правительство Москвы, рыночные реформы, приватизация, Ю.М. Лужков.
$\Pi$ о итогам выборов 1990 года политическая инициатива в органах управления Москвы перешла к «Демократической России». Оппозиция коммунистов набрала 60\% мандатов в Московском городском совете. Перед демократами стояла задача перейти из плоскости дебатов в плоскость решения насущных хозяйственных проблем города.

В результате голосования депутатов Моссовета председателем Московского городского исполнительного комитета стал Ю.М. Лужков. Ранее, когда исполнял обязанности председателя Московского городского агропромышленного комитета, он успел сникать славу «крепкого хозяйственника». На этом посту ему удалось наладить снабжение города овощами и фруктами, повысить процент сохраняемости плодов, хранящихся на овощебазах. Г.Х. Попов в одном из выступлений перед депутатами Моссовета особенно отмечал, что Ю.М. Лужкову удалось избавиться от практики принуждения жителей столицы к заготовке продовольствия.

В это время Москва бурлила из-за «табачного», «чайного» и «водочного» кризисов. Встал вопрос о введении карточного распределения продовольственных товаров. Однако, администрация города решила применить систему визитных карточек, по которым отовариваться могли только москвичи [6; С.209]. На практике же, мо- сквичу ничего не стоило по договоренности с иногородним приобрести товар в Москве и передать его своему контрагенту. Альтернативой карточкам могли послужить талоны, отсекавшие возможность получения товара иногородними более жестко. Но талон предполагал также необходимость обеспечить предъявителя товаром, а визитная карточка с этой точки зрения была менее обременительной для властей.

Кризис обеспечения охватил всю страну, но наиболее напряженная ситуация сложилась в столице, зависящей от регулярного завоза продовольствия. Москвичи толпились в очередях, но власти не могли обеспечить даже «карточный минимум» [2; C.56].

Дефицит ощущался москвичами очень остро. Роль сыграло также и то, что предприятия придерживали товар в ожидании отпуска цен.

Жители столицы ожидали скорых реформ. Ю.М. Лужков вспоминает, что движение на Тверской перекрыли таксисты, требовавшие скорой приватизации [3; С.93].

Опасность возникшей ситуации характеризует тот факт, что в стране в тот момент не хватало даже зерна для нормального рациона граждан. К концу 1991 года нормы отпусков по карточкам в большинстве регионов 
России составляли: 1 кг сахара на человека в месяц, 0,5 кг мясопродуктов, 0,2 кг животного масла. При потребности в 5 млн тонн зерна ежемесячно, в январе 1992 года государство располагало лишь тремя [7; С.220].

Кроме удручающей ситуации в хозяйственной сфере, развитие города сковывал и управленческий кризис. Поэтому началом выхода из ситуации первый мэр Москвы Г.Х. Попов объявил проведение муниципальной реформы летом 1991 года. Реформа закрепляла политический успех демократов и была призвана перераспределить возможности управления городской собственностью и бюджетом. Мосгорисполком преобразовался в Правительство Москвы, прежние 33 района столицы стали 10 административными округами, во главе с префектами. Те же делились на 124 муниципальных округа, возглавляемые супрефектами. Мэр сосредоточил в своих руках распорядительные функции, Моссовет и районные советы, напротив, потеряли свое прежнее значение.

Правительство Москвы и вице-мэр Ю.М. Лужков сыграли важную роль в августовских событиях 1991 года. Вопреки давлению КГБ и партийных органов, Юрий Михайлович подтвердил свою лояльность линии президента РСФСР. Юрий Михайлович в этих сложных условиях направил воззвание к москвичам и собрал правительство столицы с целью продолжения его штатной работы [3; C.106].

В связи с тем, что в первый день путча мэр Попов отсутствовал в командировке, Ю.М. Лужков начал организовывать сопротивление ГКЧП без него. Среди важнейших задач для Правительства Москвы в тот период были: не дать войскам заблокировать мэрию, организовать возведение баррикад у Белого дома и основных магистралях столицы, восстановить работу «Эха Москвы», попытаться склонить солдат на сторону сил сопротивления, наладить питание москвичей на баррикадах [3; C.110].

После провала путча с утра 22.08.1991 Правительство Москвы занялось вопросами оценки ущерба и разбором баррикад. Некоторое время усилия властей были направлены на восстановление нормальной жизни города [3; C.118].

Центробежные силы в СССР обернулись дезинтеграцией хозяйственных связей не только в масштабах республик, но и на уровне отдельных регионов и районов. Созданный временный орган управления, Комитет по оперативному управлению, был призван наладить более-менее стабильное снабжение граждан товарами и продовольствием. Правительство Москвы также серьезно воспринимало прогнозы экспертов о грядущей голодной зиме и вероятных голодных бунтов [3; С.127].
Указ «О свободе торговли» от 29.01.1992 привел к повсеместному возникновению стихийных торговых точек. Москва напоминала огромную «толкучку», где с рук отпускали продовольствие, одежду, домашнюю утварь и другие товары. Свобода торговли могла решить проблему дефицита продовольствия, но свободные цены не позволяли решить проблему голодных людей. Москвичи были фрустрированы и так и не смогли найти логику в том, что сметана могла стоить почти в два раза дороже сливочного масла. Ведь масло производится из самой сметаны [2; C.58-59].

В вопросе передачи гражданам права собственности на недвижимость мэр Попов настоял на скорейшей приватизации жилищной площади без каких-либо бюрократических проволочек. Предложения депутатов Моссовета о введении доплат в зависимости от величины квартиры и ее местоположения были отвергнуты [3; C.137]. Приватизация проводилась по упрощенной схеме, что, с одной стороны, позволило москвичам стать собственниками жилья. Достаточно было подать заявление домоуправу и в месячный срок оно должно было быть рассмотрено. У людей, многих из которых еще вчера ничего не было, теперь появилось в распоряжении недвижимое имущество. С другой стороны, возросли случаи незаконного присвоения чужой жилищной площади, активизировались криминальные элементы.

В июне 1992 г. в пятый раз московский мэр Г.Х. Попов подал в отставку. Поводом послужило несогласие с отдельными аспектами реформ, проводимых правительством Е.Т. Гайдара. Отставка была принята и Б.Н. Ельцин назначил хорошо ему знакомого вице-мэра Ю.М. Лужкова на должность исполняющего обязанности мэра. Теперь Юрию Михайловичу предстояло проводить курс по преодолению кризиса.

С началом «шоковой терапии», инициированной правительством Е.Т. Гайдара Москва лишилась финансирования из средств Госплана СССР. В этот период значительным источником доходов города стала приватизация предприятий легкой промышленности, таксомоторных парков, магазинов, овощных баз и т.д. [3; С.140] В то же время, уровень социального обеспечения москвичей сильно упал и Правительство Москвы должно было с этим что-то делать.

Осенью 1991 года была принята программа социально-экономического развития столицы. Стратегия московских властей была направлена на скорейшую реализацию рыночных реформ с одной стороны и социальную поддержку наиболее уязвимой части населения с другой стороны. Большее внимание по сравнению с федеральными программами уделялось поддержке трудовых коллективов, малообеспеченных слоев населе- 
ния: молодежи, пенсионеров, многодетных и инвалидов. В 1992 году была введена столичная надбавка к пенсии.

Согласно принятой программе приоритетными направлениями стали приватизация торговли, сферы услуг, автозаправочных станций, мелких и средних предприятий городской промышленности, городского транспорта.

Москва стремилась реализовать преимущества столицы в финансовом поле. Мэр Ю.М. Лужков поставил цель вывести город на уровень современных европейских мегаполисов. Экономическая необходимость определяла целесообразность создания новых объектов финансовой и торгово-посреднической инфраструктуры. Это позволило в будущем привлекать иностранные инвестиции и извлечь дивиденды для роста московской экономики.

В Москве приватизация проводилась со своей спецификой. Произошла «обвальная приватизация», когда Правительство Москвы давило на трудовые коллективы с тем, чтобы они приватизировали объекты сферы услуг [3; С.135]. Право на особую схему приватизации в столице России мэру пришлось отстоять лично, вступив в конфликт с руководителем Комитета по управлению государственным имуществом Анатолием Чубайсом. Б.Н. Ельцин согласился ввести в Москве «особый порядок приватизации», подразумевавший, что пятая часть акций, проданных компаниям, резервировалась за мэрией. Свыше половины денег за приватизацию любого московского предприятия поступало в полное распоряжение города [3; С.140].

Можно отметить, что приватизация столичной собственности осуществлялась по цене ближе к рыночной, чем в среднем по стране. Например, крупный судостроительный Балтийский завод был продан за 15 тысяч ваучеров, самый крупный в России завод тяжелого машиностроения Уралмаш был приватизирован за 130 тысяч ваучеров. В Москве ситуация сложилась иначе: гостиница «Минск» обошлась приобретателям в 200 тысяч ваучеров, продажа ЗИЛ принесла казне 800 тысяч ваучеров [2; C.51].

По мнению Ю.М. Лужкова, отличие московского порядка приватизации позволило сохранить рабочие места и пресечь широкую криминальную деятельность в этой сфере. Предприятия отпускались по стоимости, близкой к рыночной на основе проведения конкурса. Однако, это не могло остановить развал московского промышленного сектора.

В 1992 году московское правительство положило начало программе развития жилищно-строительного ком- плекса столицы. Меры стали ответом на возрастающий кризис в этом секторе: стоимость стройматериалов возрастала, покупательная способность заказчиков падала. Грозило массовое сокращение рабочих мест в сфере строительства.

В советские времена названная Егором Гайдаром «экономика нулевого цикла» стимулировала чиновников на самые простые строительные проекты - закладку фундамента для будущих домов, поликлиник, заводов. Далее строительство могло заморозиться на неопределенное время. В Москве также зияли бетонные блоки «незавершенки».

Столичное правительство стало претворять шаги в разрешении этого кризиса. Первый шаг - продолжение продажи незавершенных домов. Второй - сохранение темпов строительства муниципальных объектов образования и здравоохранения за счет городского бюджета. Третий - обеспечение строительства домов ЖСК за счет участия городского и федерального бюджетов. Четвертый - максимальное сохранение рабочих мест за москвичами. Пятый - повышение рабочих расценок и расширение льготных программ для лучших мастеров [3; C.160].

В начале 1990-х годов системе городского управления приходилось адаптироваться к неопределенности в условиях нарождающихся рыночных отношений. Чиновники привыкали к тому, что жилье нужно было не «сдавать» как ранее госкомиссии, а размещать на аукционах в надежде на то, что найдется покупатель, готовый предоставить необходимую сумму для приобретения жилья.

С середины 60-х годов XX в. ввод в эксплуатацию жилищных домов в Москве неуклонно сокращался. После распада СССР в результате принятых мер московского правительства и привлечению под строительные цели банковских кредитов удалось вызвать строительный бум в столичном регионе.

Цена квартиры в Москве стала резко расти. Объяснение этому нашли позже, выделив фактор «столичности», развитую инфраструктуру и наличие рабочих мест в близи от жилых кварталов.

В июне 1990 года по сведениям газеты «Коммерсантъ» однокомнатные квартиры стоили от \$1500 до \$3000. Осенью 1992 года ее стоимость достигла уже 15000-23000 долларов [4]. Ипотечное кредитование еще не было доступно населению, но становилась все более часто употребляемой практика «долевого» участия в строительстве. Впервые за 30 лет в Москве наметился рост числа ежегодно вводимых в эксплуатацию жилищ- 
ных домов.

Московский бюджет получил большую прибыль от роста цен на столичную недвижимость. Для закрепления успеха была введена муниципальная наценка $30 \%$ на продажу жилья, которая распределялась строительным компаниям на постройку бесплатного жилья для москвичей-очередников [3; С.162].

Ряд мер, проводимых Правительством Москвы и мэ- ром в начале 1990-х годов, позволил стабилизировать ситуацию в отдельных сферах жизни горожан. Социальная поддержка могла быть недостаточной в сравнении с масштабами кризиса, однако, москвичи смогли почувствовать себя полноправными владельцами недвижимого имущества и у многих появилась возможность сохранить свои рабочие места. Обеспечение горожан продовольствием и другими товарами стало налаживаться. Столица смогла пополнить свой бюджет и создать основу для последующего развития города.

\section{ЛИТЕРАТУРА}

1. Вострышев М.И. Москва ельцинская. Хроники президентского правления. Москва : Родина, 2021. 528 с.;

2. История современной России. Десятилетие либеральных реформ: 1991-1999 гг. / Пихоя Р.Г., Журавлев С.В., Соколов А.К. Москва : Новый хронограф, 2011. 312 c.;

3. Лужков Ю.М. Москва и жизнь. Москва : Эксмо, 2017. 237 с.;

4. Морозов М. Рынок недвижимости в Москве // Коммерсантъ. 1993. № 179.;

5. Пихоя Р.Г. Москва. Кремль. Власть. Две истории одной страны: Россия на изломе тысячелетий. 1985-2005. Москва : Русь-0лимп, 2007. 551 с.;

6. Согрин В.В. Политическая история современной России, 1985-1994: От Горбачева до Ельцина. Москва : Прогресс-Академия, 1994. 192 с.;

7. Травин Д.Я. Очерки новейшей истории России. Книга первая: 1985-1999. СПб. : Норма, 2010. 368 с.

(с) Щукин Алексей Александрович (AAShchukin95@yandex.ru).

Журнал «Современная наука: актуальные проблемы теории и практики»

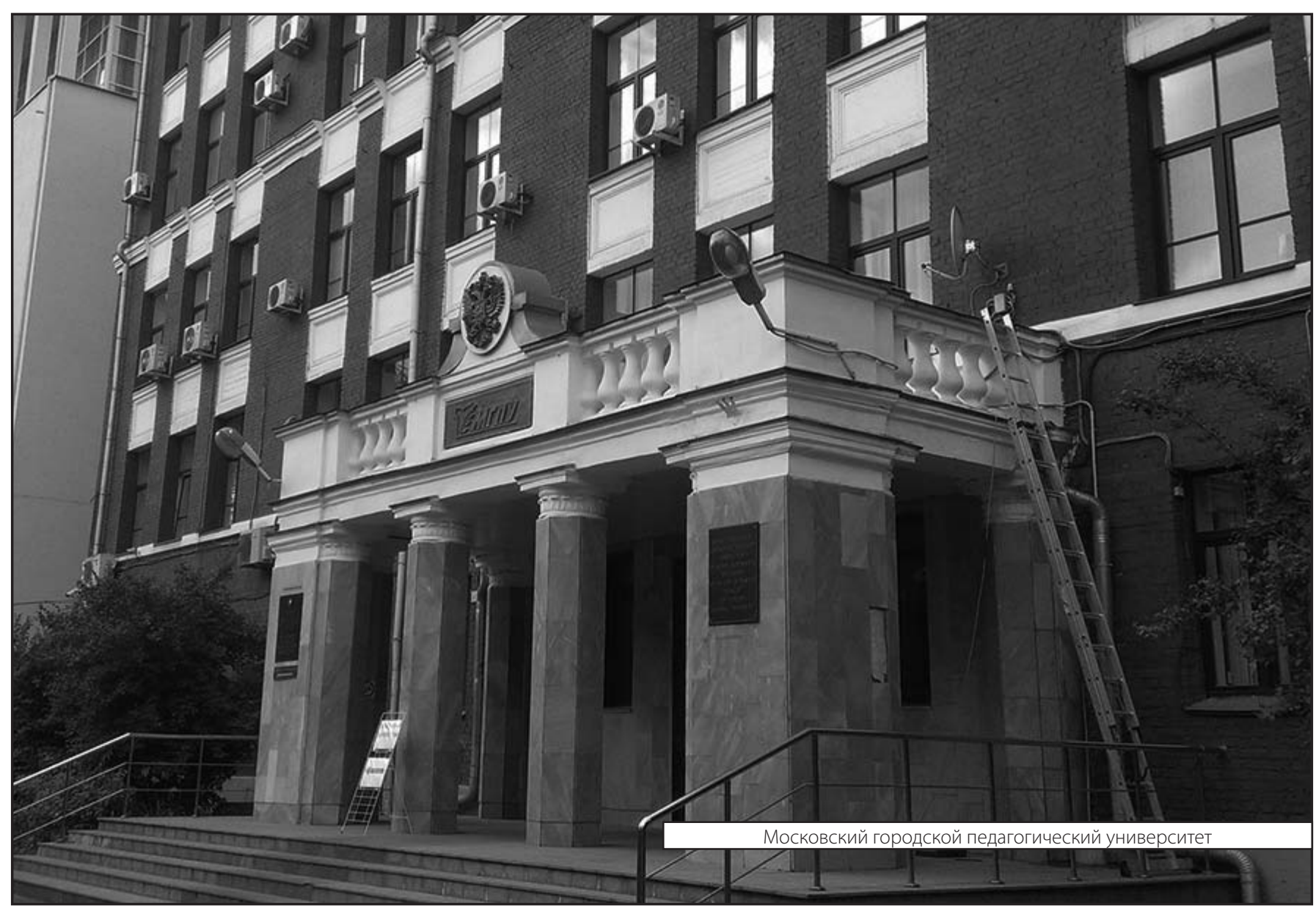

